\title{
New particle formation events measured on board the ATR-42 aircraft during the EUCAARI campaign
}

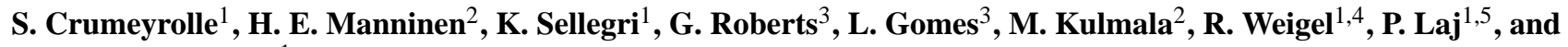 \\ A. Schwarzenboeck ${ }^{1}$ \\ ${ }^{1}$ Laboratoire de Météorologie Physique (UMR6016), Université Blaise Pascal, Clermont-Ferrand, France \\ ${ }^{2}$ Department of Physics, University of Helsinki, P.O. Box 64, 00014 Helsinki, Finland \\ ${ }^{3}$ Centre National de Recherches Météorologiques, Météo-France, Toulouse, France \\ ${ }^{4}$ Institute for Physics of the Atmosphere, Johannes Gutenberg University, Mainz, Germany \\ ${ }^{5}$ Laboratoire de Glaciologie et Géophysique de l'Environnement, Université de Grenoble 1/CNRS, Grenoble, France
}

Received: 25 March 2010 - Published in Atmos. Chem. Phys. Discuss.: 14 April 2010

Revised: 13 July 2010 - Accepted: 13 July 2010 - Published: 22 July 2010

\begin{abstract}
Aerosol properties were studied during an intensive airborne measurement campaign that took place at Rotterdam in Netherlands in May 2008 within the framework of the European Aerosol Cloud Climate and Air Quality Interactions project (EUCAARI). The objective of this study is to illustrate seven events of new particle formation (NPF) observed with two Condensation Particle Counters (CPCs) operated on board the ATR-42 research aircraft in airsectors around Rotterdam, and to provide information on the spatial extent of the new particle formation phenomenon based on 1-s resolution measurements of ultra-fine particle (in the size range 3-10 nm diameter, denoted $\mathrm{N}_{3-10}$ hereafter) concentrations. The results show that particle production occurred under the influence of different air mass origins, at different day times and over the North Sea as well as over the continent. The number concentration of freshly nucleated particles $\left(\mathrm{N}_{3-10}\right)$ varied between 5000 and $100000 \mathrm{~cm}^{-3}$ within the boundary layer (BL). Furthermore the vertical extension for all nucleation events observed on the ATR- 42 never exceeded the upper limit of the BL. The horizontal extent of $\mathrm{N}_{3-10}$ could not be delimited due to inflexible flight plans which could not be modified to accommodate real-time results. However, the NPF events were observed over geographically large areas; typically the horizontal extension was about $100 \mathrm{~km}$ and larger.
\end{abstract}

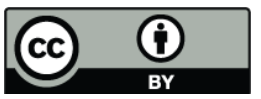

Correspondence to: S. Crumeyrolle (s.crumeyrolle@opgc.univ-bpclermont.fr)

\section{Introduction}

The atmospheric aerosol particle formation and processing results from complex sets of homogeneous and heterogeneous physicochemical processes. The smallest particles are either formed from supersaturated vapour in absence of any seed nuclei acting as a condensation surface, the so-called homogeneous nucleation (Kulmala, 2003), or due to the process of ion-induced nucleation (Yu and Turco, 2000; Curtius, 2006). The formation and growth of these initial clusters to detectable sizes $(D p>2-3 \mathrm{~nm})$ is counteracted by their simultaneous removal from the ultra fine particle mode by coagulation with the pre-existing aerosol particle population (Kerminen et al., 2001; Kulmala, 2003). Because of the two competitive processes of homogeneous/heterogeneous particle nucleation plus growth and condensation of gas-phase species onto the pre-existing particle populations, the number concentration of particles smaller than $20 \mathrm{~nm}$ has been observed to be anti-correlated with the aerosol volume and mass (Rodriguez et al., 2005). Hence, an increase of the nucleation mode aerosol number concentration during nucleation events would mean that the total aerosol volume is rather small. However, a more profound understanding of processes modifying the nucleation mode particle number and size distributions is clearly needed. Indeed nucleation particles received increasing attention as a potentially important source of aerosol particles affecting climate and human health.

Published by Copernicus Publications on behalf of the European Geosciences Union. 
Homogeneous nucleation events in the atmosphere have been observed around the world (Kulmala et al., 2004a; Kulmala and Kerminen, 2008) in various environments from the boundary layer (BL) at urban locations (Wehner and Wiedensohler, 2003; Ganguli et al., 2006; Lonati et al., 2006; Tuch et al., 2006) to remote polar background areas (Komppula et al., 2006; Virkkula et al., 2007) and in the free troposphere (Venzac et al., 2008). Brock et al. (1995) suggest the homogeneous nucleation to form aerosol of a binary solution of sulphuric acid and water in the Tropical Tropopause Layer (TTL) providing a source of the background stratospheric aerosol, i.e. for the Junge Layer aerosol (Junge et al., 1961). Current knowledge of submicron aerosol has generally identified the number size distribution to be composed of a Nucleation mode (3-10 $\mathrm{nm}$ diameter) representative of recent new particle formation, an Aitken mode (40-80 nm diameter) and an accumulation mode (100-300 nm diameter) representing more aged particles (Kulmala et al., 2004b). The aerosol size distributions have been classically described as a function of the air mass type (marine, continental, mixed) (Birmili et al., 2001; O'Dowd et al., 2001; Tunved et al., 2005, Venzac et al., 2009). However, even within the same air mass type, the aerosol may be rapidly transformed by input of additional reactant sources (particles or gases), dilution, or deposition and coagulation processes within few tens of hours, leading to major differences in aerosol particle size distributions, chemical composition, state of mixture (internal or external) and thus their physico-chemical behaviour, even when comparing locations separated by a few hundreds of kilometres (Tunved et al., 2005).

The occurrence of new particle formation episodes depends on various factors including emissions strength of precursors, composition and number concentration of preexisting aerosol population, meteorological parameters (in particular solar radiation, temperature and relative humidity) and photo-chemical processes (Kulmala et al., 2001, 2003). Air masses of different origins have different meteorological, physical and chemical characteristics, and therefore the probability of occurrence of new particle formation (NPF) events at a given location and time depends not only on local emissions, but also on long range transport (Sogacheva et al., 2005, 2007; Tunved et al., 2006). Moreover, regarding the spatial extension of NPF events, some important questions arise: does nucleation occur in the free troposphere or in the BL? What is the horizontal extend of NPF events, and are they homogeneously distributed over this spatial scale?

The European Aerosol Cloud Climate and Air Quality Interactions (EUCAARI, Kulmala et al., 2009) project has been created to investigate the effects of aerosol particles on climate and air quality. Quantifying the effect of aerosols on the planet's radiative balance is one of the most urgent tasks in our effort to understand future climate change (IPCC, 2007). As a whole, the contribution of the various aerosol sources, the role of long-range transport, and the contribution of primary and secondary particulate matter to the at- mospheric aerosol concentrations over Europe are still not well known. Particularly uncertain remain the aerosol parameters influencing the radiative balance and the properties of clouds (Adams and Seinfeld, 2002; Kaufman et al., 2002; Spichtinger and Cziczo, 2008), such as the number size distribution, chemical composition and particle mixing state. The EUCAARI observational system consists of long-term and spatially extensive surface-based measurements, including the European network of supersites for aerosol research (EUSAAR, Philippin et al., 2009). In addition, the use of satellites contributes to understanding regional aerosol variations and provides the spatial distribution of aerosol and cloud properties (Meskhidze et al., 2009).

Within the frame of the EUCAARI project an intensive measurement campaign including the deployment of European instrumented research aircraft (DLR Falcon-20, British Bae-146, NERC Dornier, French ATR-42 and French Falcon-20) have been performed in May 2008. Some of the results from these flights have already been reported for example by Mirme et al. (2010). The French ATR-42 has been equipped with state-of-the-art aerosol and cloud instrumentation. The study presented here focuses on the measurements of nucleation mode particles (concentrations, vertical and horizontal extension) on board the ATR-42 aircraft. Lagrangian back-trajectory calculations were used to interpret the impact of the air masses origin on the frequency and intensity of observed nucleation mode particles and thus, related to a NPF event.

The following section (Sect. 2), describes briefly the airborne sampling strategy as well as the data set of measured aerosol properties, whereas the basic findings of this study are presented in Sect. 3, by presenting the air mass analysis via back-trajectories correlated to nucleation mode particle observations.

\section{Methods}

Within the European integrated project EUCAARI on aerosol-cloud-climate research, west-east and north-south station-to-station networks including the Cabauw (CBW) supersite have been used together with quasi-Lagrangian and Eulerian airborne measurements in order to quantify the effects of emissions on regional aerosol properties, and to study aerosol formation, processing, transport and deposition. To improve our understanding on processes related to atmospheric aerosol physics and chemistry, from nanometer scale to the overall aerosol-cloud-climate scale, the EUCAARI intensive observation campaign, including deployment of research aircraft, has been performed in May 2008.

\subsection{Ground based measurements}

The Cabauw (CBW) field site is located in the western part of the Netherlands $\left(51.971^{\circ} \mathrm{N}, 4.927^{\circ} \mathrm{E}, 0.7 \mathrm{~m}\right.$ below sea level), 
Table 1. Overview of ATR-42 flights performed during the EUCAARI campaign: day, times, Flight number and plans of all flights. The prevailing atmospheric flows at low level $(850 \mathrm{hPa})$ and observation flag of new particle formation (NPF) event at Cabauw (from SMPS and NAIS measurements) and on-board the ATR-42 (from SMPS measurements) are added.

\begin{tabular}{ccccccc}
\hline Day & $\begin{array}{c}\text { Take-off-Landing } \\
\text { time (UTC) }\end{array}$ & $\begin{array}{c}\text { Flight } \\
\text { type }\end{array}$ & $\begin{array}{c}\text { Flight } \\
\text { number }\end{array}$ & $\begin{array}{c}\text { Prevailing atmospheric } \\
\text { flow }\end{array}$ & \multicolumn{2}{c}{ NPF event } \\
Cabauw & ATR-42 \\
\hline 2 May 2008 & $08: 40-10: 09$ & RF_type_1 & 42 & West & $\mathrm{N}$ & $\mathrm{N}$ \\
5 May 2008 & $11: 04-14: 20$ & RF_type_2 & 43 & South-East & $\mathrm{Y}$ & $\mathrm{Y}$ \\
6 May 2008 & $08: 57-10: 27$ & RF_type_2 & 44 & South-East & $\mathrm{Y}$ & $\mathrm{Y}$ \\
8 May 2008 & $11: 54-15: 24$ & RF_type_2 & 45 & South-East & $\mathrm{Y}$ & $\mathrm{Y}$ \\
9 May 2008 & $06: 04-07: 53$ & RF_type_3 & 46 & South-East & $\mathrm{N}$ & $\mathrm{N}$ \\
9 May 2008 & $11: 37-14: 57$ & RF_type_3 & 47 & South-East & $\mathrm{Y}$ & $\mathrm{N}$ \\
11 May 2008 & $09: 55-12: 45$ & RF_type_2 & 48 & South-East & $\mathrm{Y}$ & $\mathrm{Y}$ \\
13 May 2008 & $12: 55-15: 55$ & RF_type_1 & 49 & South-East & $\mathrm{N}$ & $\mathrm{N}$ \\
14 May 2008 & $12: 13-15: 05$ & RF_type_1 & 50 & South-East & $\mathrm{Y}$ & $\mathrm{Y}$ \\
15 May 2008 & $06: 19-09: 50$ & RF_type_4 & 51 & South-East & $\mathrm{N}$ & $\mathrm{N}$ \\
15 May 2008 & $11: 49-15: 06$ & RF_type_4 & 52 & South-East & $\mathrm{N}$ & $\mathrm{N}$ \\
18 May 2008 & $08: 50-11: 10$ & RF_type_5 & 53 & North-West & $\mathrm{Y}$ & $\mathrm{Y}$ \\
18 May 2008 & $12: 01-14: 45$ & RF_type_5 & 54 & North-West & $\mathrm{Y}$ & $\mathrm{Y}$ \\
19 May 2008 & $11: 06-14: 24$ & RF_type_1 & 55 & North-West & $\mathrm{Y}$ & $\mathrm{Y}$ \\
20 May 2008 & $09: 02-11: 06$ & RF_type_1 & 56 & North-West & $\mathrm{N}$ & $\mathrm{N}$ \\
21 May 2008 & $10: 07-12: 06$ & RF_type_1 & 57 & North-West & $\mathrm{N}$ & $\mathrm{N}$ \\
21 May 2008 & $13: 45-15: 14$ & RF_type_1 & 58 & North-West & $\mathrm{N}$ & $\mathrm{N}$ \\
26 May 2008 & $11: 59-15: 20$ & RF_type_5 & 59 & South-West & $\mathrm{N}$ & $\mathrm{N}$ \\
28 May 2008 & $07: 54-09: 55$ & RF_type_6 & 60 & South-West & $\mathrm{N}$ & $\mathrm{N}$ \\
28 May 2008 & $13: 24-15: 40$ & RF_type_1 & 61 & South-West & $\mathrm{Y}$ & $\mathrm{Y}$ \\
29 May 2008 & $13: 15-14: 36$ & RF_type_1 & 62 & South-West & $\mathrm{N}$ & $\mathrm{Y}$ \\
30 May 2008 & $11: 26-14: 42$ & RF_type_5 & 63 & South-West & $\mathrm{N}$ & $\mathrm{N}$ \\
\hline
\end{tabular}

$35 \mathrm{~km}$ east of Rotterdam. The air masses arriving to this rural site are typically originating from clean marine sector from the north or from polluted continental Europe. The speciality in CBW is the $213 \mathrm{~m}$ high mast which allows for sampling at different altitudes and hence is used to establish relations between the state of the lowermost atmospheric BL, aerosol particles, clouds, the weather situation, and land surface conditions (Van Ulden and Wieringa, 1996).

The Neutral cluster and Air Ion Spectrometer (NAIS, Kulmala et al., 2007) was measuring aerosol sampled through an inlet installed at $60 \mathrm{~m}$ height on the CBW mast. The NAIS measures simultaneously electrical mobility distributions of both negative and positive air ions and total particles in the range from 2.39 to $0.001 \mathrm{~cm}^{2} \mathrm{~V}^{-1} \mathrm{~s}^{-1}$, which corresponds to a mobility diameter range of $0.8-40 \mathrm{~nm}$ for ions and in case of particles $\sim 2-40 \mathrm{~nm}$. Controlled corona charging together with electrical filtering also enables measurements of the neutral aerosol particles down to $\sim 2 \mathrm{~nm}$. The instrument consists of two identical cylindric differential mobility analyzers where the sample is collected to insulated electrometer rings at the outer electrode. A more detailed description of the instrument and examples of its atmospheric applications can be found in Manninen et al. (2009).

\subsection{Instrumented ATR-42 aircraft}

During May 2008 the French ATR-42 research aircraft operated by SAFIRE (Service des Avions Français Instrumenté pour la Recherche en Environnement) was based at Rotterdam airport in the Netherlands for the duration of the EUCAARI intensive observation period. A total of 22 research flights was performed between 2 May and 30 May 2008 (Table 1). For the present study these 22 flights are grouped into six different types of Research Flights (RF_type_n, Fig. 1). The 9 flights corresponding to type RF_type_1 show flight patterns which were centred at and around the ground-based measurement area of CBW supersite. The objectives of these flights were to specify origins and regional characteristics of the air masses sampled at Cabauw, thus correlating aircraft characterization of the vertical structure of the atmosphere above Cabauw with the ground-based measurements at the supersite and the IfT-helicopter platform (Wehner et al., 2010).

Since the occurrence of the NPF phenomenon in the proximity of the oceans and seas is still not well understood (O'Dowd et al., 2007), nucleation particle concentration observations near the coastline of the North Sea are of great interest in our study. This type of research flight close to the coastline is denoted type RF_type_2 with a total of four 


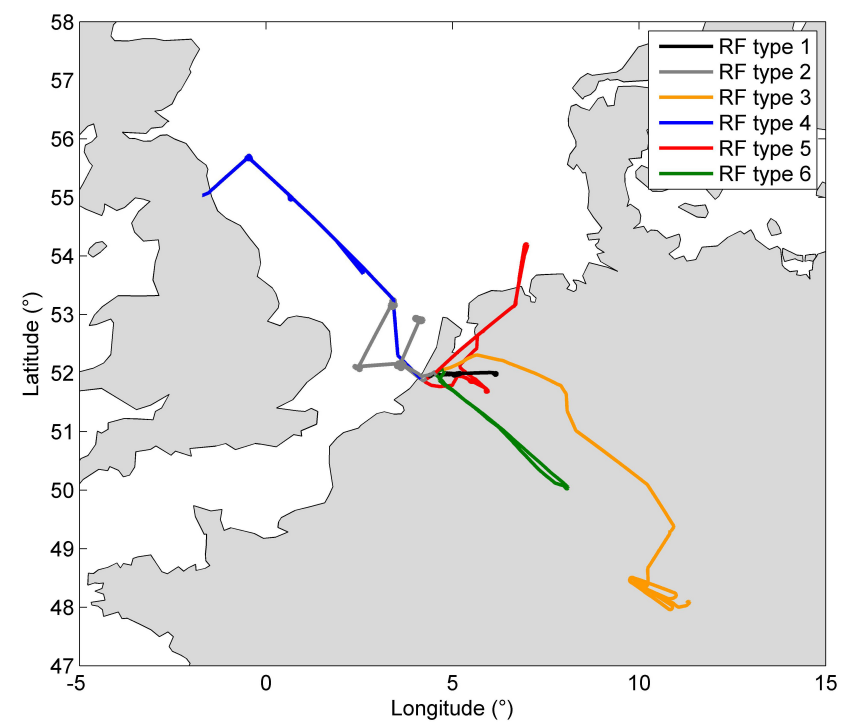

Fig. 1. Different types of research flight (RF) plans performed during the EUCAARI intensive observation campaign in May 2008.

corresponding flights. The goals of RF_type_3 / RF_type_4 / RF_type_5 / RF_type_6 (number of flights is 2, 2, 4, and 1 respectively) aimed at studies related to aerosol properties along "quasi-Lagrangian" flight tracks: West-East and North-South transects, most of the time in coordination with the British Bae-146, DLR-Falcon 20 flights and ground sites.

The deployment of the French research aircraft ATR-42 has been particularly dedicated to aerosol-cloud interaction research as already made in previous recent studies (Crumeyrolle et al., 2008; Matsuki et al., 2010). The aerosol instrumentation has been connected to the ATR-42 community aerosol inlet (CAI) and switched to the Counterflow Virtual Impactor (CVI, Schwarzenboeck et al., 2000) during cloud measurements. The isokinetic and isoaxial CAI, based on the University of Hawaï shrouded solid diffuser designed by A. Clarke and modified by Meteo France, has a $50 \%$ sampling efficiency for particle size higher than $5 \mu \mathrm{m}$ (McNaughton et al., 2007; Gomes et al., 2010).

The relevant aerosol instrumental setup (for the presented aerosol nucleation study) consisted of two condensation particle counters (CPC, McMurry, 2000), one TSI model 3025 with measured nominal 50\% lower cut-off diameter of $3 \mathrm{~nm}$ and one TSI model 3010 with a cut off diameter of $10 \mathrm{~nm}$ (Mertes et al., 1995; Stolzenburg and McMurry, 1991), and a SMPS (Scanning Mobility Particle Sizer) measuring particle size distribution between $20-500 \mathrm{~nm}$. The SMPS system consisted of a TSI model 3010 condensation particle counter, a DMA (Differential Mobility Analyzer) as described by Villani et al. (2007) and a krypton aerosol neutralizer (Kr-85). The sheath flow rate was controlled with a critical orifice in a closed loop arrangement (Jokinen and Mäkelä, 1996). Typically the scan time was chosen to be $90 \mathrm{~s}$. Thus, within the entire instrumental setup on the ATR-42 aircraft, we were able to record nucleation mode particle concentrations by subtracting the data readings of TSI-3025, TSI-3010 (i.e. using the 50\% cut-size for respective CPCs), and SMPS integral concentrations. To take into account the coincidence effect, particle concentrations were corrected using the equation given by the producer specifications. In this way we deduced estimates of the ultrafine particle concentrations between 3-10 nm $\left(\mathrm{N}_{3-10}\right), 3-20 \mathrm{~nm}\left(\mathrm{~N}_{3-20}\right)$ and $10-20 \mathrm{~nm}$ $\left(\mathrm{N}_{10-20}\right)$. The time resolution of CPC counters was set to $1 \mathrm{~s}$, with relative uncertainties in concentration measurements of about $5 \%$ according to the producers specifications.

Besides, the ATR-42 was equipped with state of the art aerosol instrumentation (PSAP, Bond et al., 1999), nephelometer (TSI 3563, TSI Inc., St Paul, MN), Aerosol Mass Spectrometer (AMS, Jayne et al., 2000; Drewnick et al., 2005; Canagaratna et al., 2007), particle counting/sizing instruments, and cloud (Fast Forward Scattering Spectrometer Probe, Fast-FSSP, Brenguier et al., 1998).

\section{Results}

\subsection{Observation of atmospheric nucleation}

New particle formation (NPF) events are frequently monitored on single measurement sites, where contour plots of the temporary evolution of nucleation particle size spectra are utilised to illustrate distinct features of the new particle formation and growth. Within EUCAARI a NPF event classification was performed visually from the NAIS and SMPS data measured at the CBW ground based site and ATR-42, respectively. NPF event classification follows methods introduced earlier by Dal Maso et al. (2005). The time series of the particle size distributions have been studied visually, and the subsequent "event" or "non-event" classification is based on this analysis. Days were classified either as event days, showing a clear new particle formation burst in the data or as non-event days with no sign of new ultrafine particle appearance, or finally undefined days, where some ultrafine particles were present but it was not evident that new particle formation was taking place. To qualify a day as an event day, a new particles mode had to appear in the size distribution in the nucleation mode $(<25 \mathrm{~nm})$ and prevail continuously for more than one hour. Furthermore, the size of the new particles needs to increase with time; the latter requirement was accounted for by particle formation occurring over a large region, and thus producing a significant amount of potentially growing nucleation mode aerosol particles.

In addition to the NPF observation at the CBW site, considerable amounts of nucleation mode particles, thus related to NPF events, have been observed during 10 out of 22 research flights performed with the ATR-42.

The NPF observations could be associated to all types of research flights from RF_type_1 to RF_type_6. Most of the time, when NPF events were observed with the aircraft CPCs 
and SMPS, the phenomenon was simultaneously observed with the NAIS and SMPS at the CBW supersite. As a consequence, the new particle formation was not limited to a local small scale nucleation source, but was a spatially widespread phenomenon. The overview of the nucleation observations at the CBW supersite and ATR-42 measurements is given in Table 1. Only in two cases (9 and 29 May 2008), the nucleation mode particle event observations differ when comparing the CBW ground site measurements with the aircraft observations. Indeed, on 9 May, the NPF event was observed over the CBW ground site while the ATR-42 (Flight 47) flew from Oberpfaffenhofen (Germany) to CBW. For the case of 29 May, the NPF event is observed with the ATR-42 in an air sector $150 \mathrm{~km}$ east of CBW, but not at CBW supersite.

The horizontal and vertical extension of the nucleation mode particles observed during four flights (RF44, RF55, RF56 and RF62) are on the scale of only a few kilometres, and not subject of further study here. Only seven flights showing nucleation mode particles $(3-10 \mathrm{~nm})$ on a large scale will be considered in this study. All the seven events with observed nucleation mode particles happened during the daytime (10:00-16:00), which is consistent with earlier observations (Dal Maso et al., 2005; Kuang et al., 2008; Laaksonen et al., 2008; Yu et al., 2008), where NPF events are reported to be observed frequently in very different locations (Mäkelä et al., 1997; Birmili and Wiedensohler, 2000; O'Dowd et al., 2007). The nucleation mode particles have been observed in the BL during different day times: (a) during the morning (before 11:00, flight 53), (b) during the early afternoon (before 16:00, flight 61), but mostly (c) at midday (before 14:00, RF43, RF45, RF48, RF50, RF54). Then, 45\% of NPF events were detected at noon, $33 \%$ were observed in the afternoon and only $11 \%$ in the morning. These frequencies are consistent with continuous measurements at different ground sites (Dal Maso et al., 2004; Vehkamäki et al., 2004; Dal Maso et al., 2008; Hussein et al., 2008; Kuang et al., 2008; Laaksonen et al., 2008; Yu et al., 2008).

\subsection{Air mass origins}

For all ATR-42 flights performed during EUCAARI IOP, air mass back trajectories have been calculated from HYSPLIT (Draxler et al., 2003) along the ATR flight path regardless of occurrence of the nucleation mode particles. For all ATR-42 flights, the prevailing atmospheric flows in the BL are given in Table 1. Back-trajectories have been calculated $24 \mathrm{~h}$, and $48 \mathrm{~h}$ backward in time. Thus, the respective air mass origin, once calculated, has been attributed to the corresponding segment of the aircraft path. Figure 2 represents the frequencies (colour coded from 0-1) of observed nucleation mode particles as a function of air mass origin (squares) determined for two chosen back-trajectory calculation times of $24 \mathrm{~h}$ (Fig. 2a), and $48 \mathrm{~h}$ (Fig. 2b). The numbers associated to each square denote the total number of calculated air mass origins assigned from back trajectory calculations for a)

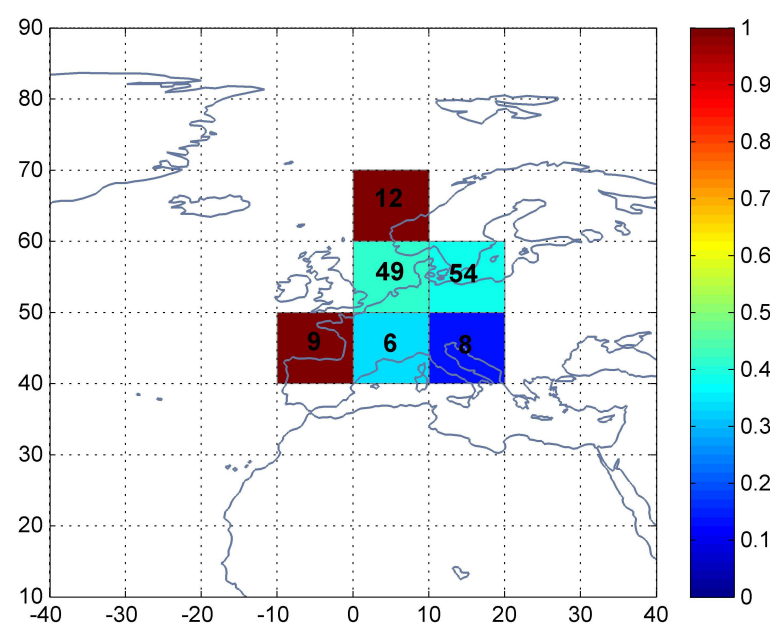

b)

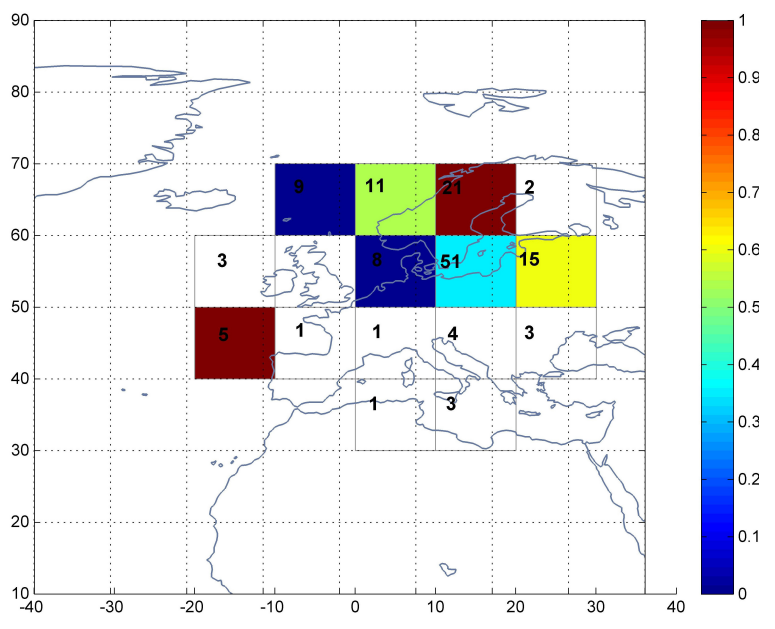

Fig. 2. Frequencies (colour coded from 0-1) of observed particle formation as a function of air mass origins (squares) determined for two chosen back-trajectory calculation times of $24 \mathrm{~h}$ (a) and $48 \mathrm{~h}$ (b). The numbers associated to each square denote the total number of calculated air mass origins assigned to the complete set of EUCAARI flights horizontally divided into equidistant flight segments, for which calculations have been performed.

the complete set of EUCAARI flights (flight segments were selected in a horizontally equidistant way, then 138 backtrajectories were calculated subsequently). To represent only statistically significant results, only the NPF probability calculated when the total number of air masses is higher than five are represented in Fig. 2a and $b$.

As a consequence of the air mass dispersion, the total number of air masses originating in one specific square, in general, decreases with time for each calculated back-trajectory (from 24 to 48 h). For trajectory calculation of 24 h (Fig. 2a), the majority of the "air mass origins" sampled by the ATR-42 stemmed from the South of Scandinavia (115 back-trajectory origins). The probability of NPF is highest for air masses originating from the western Scandinavia and the South-West 
Table 2. Tide conditions during the Group I and Group III events observed during five flights.

\begin{tabular}{ccccccc}
\hline Date & $\begin{array}{c}\text { Flight } \\
\text { number }\end{array}$ & $\begin{array}{c}\text { ATR-42 leg } \\
\text { times (UTC) }\end{array}$ & $\begin{array}{c}\text { Low tide } \\
\text { times (UTC) }\end{array}$ & $\begin{array}{c}\text { High tide } \\
\text { times (UTC) }\end{array}$ & $\begin{array}{c}\text { Low sea } \\
\text { level (m) }\end{array}$ & $\begin{array}{c}\text { High sea } \\
\text { level (m) }\end{array}$ \\
\hline 5 May 2008 & 43 & $12: 57-13: 06$ & $06: 46$ & $12: 43$ & 0.00 & 4.88 \\
8 May 2008 & 45 & $14: 26-14: 47$ & $09: 05$ & $14: 54$ & 0.26 & 4.50 \\
11 May 2008 & 48 & $12: 20-12: 41$ & $11: 36$ & $17: 32$ & 0.91 & 3.74 \\
18 May 2008 & 53 & $08: 35-09: 10$ & $06: 17$ & $12: 11$ & 0.33 & 4.40 \\
18 May 2008 & 54 & $13: 00-13: 51$ & $18: 31$ & & 0.52 & \\
\hline
\end{tabular}

of Europe and it is lowest when air masses are coming from South-East of Europe $(<20 \%)$. The analysis demonstrated that the probability of NPF occurrence is higher than $90 \%$ (Fig. 2b), when the air masses originated from the SouthWest of Europe or from North of Scandinavia. One hypothesis to explain the observation may be the transport of air masses with low background particle concentration and high concentration of gaseous sulphate and/or organic species (Clarke et al., 1998; O’Dowd et al., 1998, 1999; Komppula et al., 2006; Metzger et al., 2010). Since measurements of these gases have not been performed on-board the ATR-42, the hypothesis that those (clean) air masses with lower particle concentrations contain high concentrations of gaseous aerosol precursors and which have been transported to the air sectors of NPF observations cannot be proven. In addition, air masses with initially high particle concentrations, as for example air masses originating from Eastern Europe do not seem to be favourable to NPF events.

\subsection{Horizontal and vertical extension of NPF events}

While in the preceding sections, all flights (including NPF events and nonevents) have been treated in common, in this section, only results from flights during which nucleation mode particles have been observed will be used to determine the vertical and the horizontal extension of these events. To highlight the atmospheric structure more in detail, Figs. 3 to 6 present horizontal cross sections of the aircraft flight path with measured $\mathrm{N}_{3-10}$ observed during six flights at a constant level static pressure. The grey line corresponds to the flight track when aerosol particles were analysed in clear sky conditions. During some of the research flights in the vicinity of the Rotterdam airport, the $\mathrm{N}_{3-10}$ particle concentration has been high, probably as a consequence of fine mode aerosol production or of high gas phase concentrations due to aircraft activity or local urban pollution. Therefore, observations made around the airport will not be taken into account here.

Particle formation episodes are complex and depend on various factors including pre-existing aerosols, emission of precursors, meteorological parameters, topography and photo-chemical processes (Kulmala et al., 2001, 2003). The relationship between particle formation events and pollution levels (in terms of accumulation mode particle number concentrations) has been studied, without clear correlations. Due to the lack of statistics, this classification as a function of air pollution levels is limited. Thus, the following sections will focus on correlations between particle formation events, the origin of air masses and geographic location of nucleation events.

\subsubsection{Horizontal extension}

While for one of the six ATR-42 flights (flight 61) we can give the horizontal extension at least along the flight path of observed nucleation mode particles, this is not possible for the other five flights. The ATR-42 flight path for those flights (flights 43, 45, 48, 53 and 54) could not reach the limit of the event in its horizontal extension. In the next paragraphs, the six flights with NPF events are discussed in further detail. To study the horizontal extension of NPF events, flight legs are classified into four groups: Group I events occurred under continental South-East flow and were observed over the sea, Group II events occurred under continental SouthEast flow but were observed over the continent, Group III events occurred under marine flow and were observed over the continent and Group IV events occurred under continental South-West flow and were observed over the continent.

Events of Group I events were observed during three flights: RF43 on 5 May 2008 (Fig. 3a), RF45 on 8 May 2008 (Fig. 3b) and RF48 on 11 May 2008 (Fig. 3c). For these three flight cases, air masses were transported from the continent to the North Sea in a south-eastern flow. Recent studies (O'Dowd et al., 2002a, b) showed that NPF events in a coastal environment are linked with biogenic vapours which are greatly enhanced during the low tide period. The tide conditions have been determined (Table 2) using data from the French "Service Hydrographique et Océanographique de la Marine" (http://www.shom.fr/). The NPF events of RF43 and RF45 occurred when the sea was at its highest level, meaning that these events are probably more influenced by transport of pollution from cities close to the coastline while the NPF event of the RF48 might probably be linked to emission of biogenic gas, such as halocarbon species (Carpenter 
a)

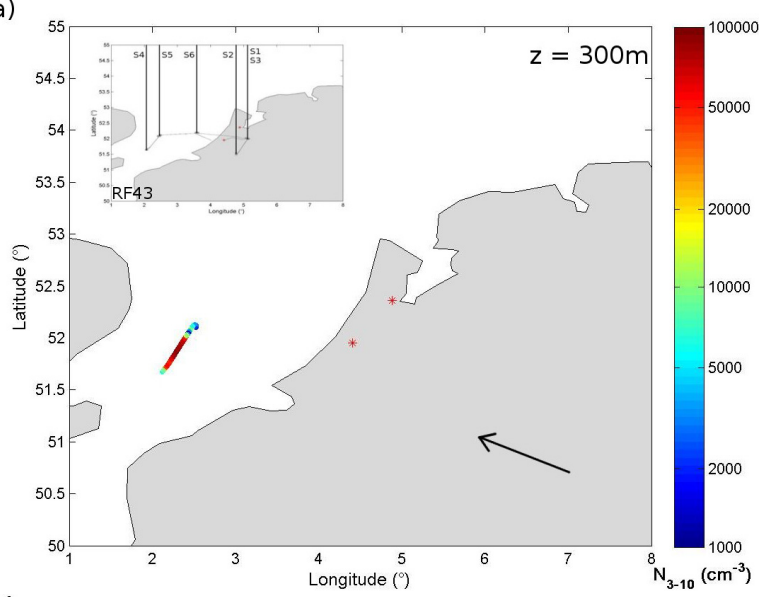

b)

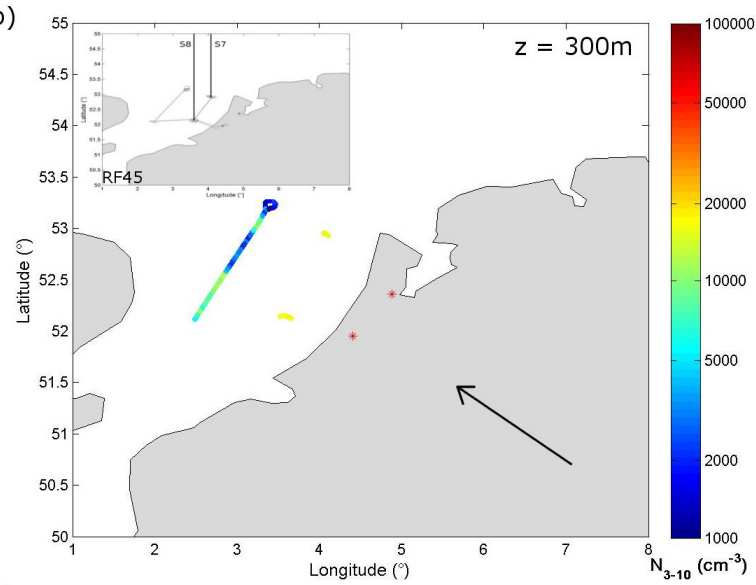

c)

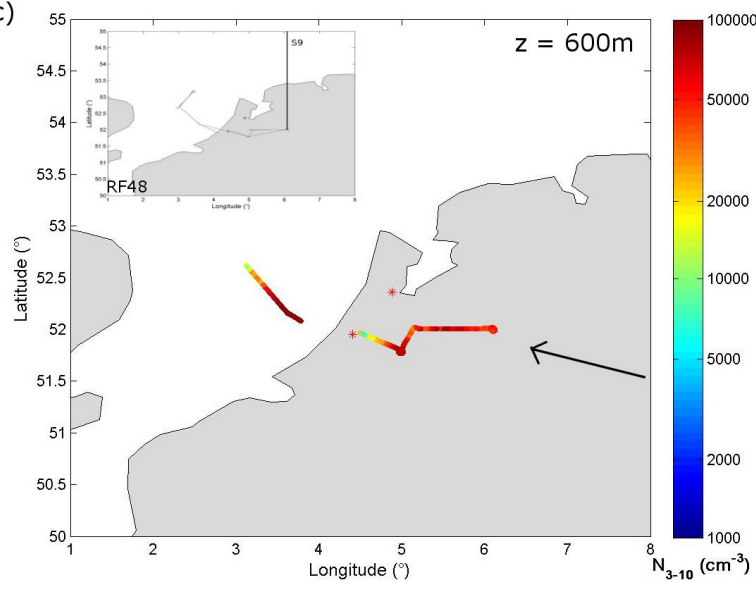

Fig. 3. Horizontal cross sections showing nucleation mode aerosol concentrations of Group I events within the size range of 3-10 nm along the ATR-42 flight trajectories during research flights (a) RF43 on 05 May, (b) RF45 on 08 May, and (c) RF48 on 11 May. Only $\mathrm{N}_{3-10}$ at a constant flight leg altitude, indicated on each figure, are represented. The black arrows represent the mean direction of the air mass (deduced from back-trajectories calculated with Hysplit (http://ready.arl.noaa.gov/HYSPLIT.php). The vertical black lines refer to the ATR-42 sounding numbers as they appear in Fig. 7. et al., 1999, 2000; Laturnus et al., 2000), from stressed biota during low tide conditions. The NPF event observed during RF43 was horizontally spread out over spatially very limited area $(40 \mathrm{~km})$ suggesting a NPF burst occurred here compared to the NPF events observed over the sea during research flights RF45 and RF48 with horizontal extensions higher than $100 \mathrm{~km}$.

Furthermore, comparing both ATR-42 legs parallel to the coastline (RF43, RF45), the $\mathrm{N}_{3-10}$ is homogeneously distributed on RF43 (Fig. 3a) and shows more inhomogeneous character during the RF45 (Fig. 3c). During the RF43, the $\mathrm{N}_{3-10}$ reached high concentration $\left(80000 \mathrm{~cm}^{-3}\right)$, whereas during RF45, the $\mathrm{N}_{3-10}$ was lower than $18000 \mathrm{~cm}^{-3}$. This inhomogeneity in $\mathrm{N}_{3-10}$ concentrations during RF45 seems to be a consequence of surface wind speed inhomogeneities. Indeed, along the flight track the concentration of particles with diameter higher than $50 \mathrm{~nm}$ $\left(\mathrm{N}_{50}\right)$ fluctuate between 1000 and $12000 \mathrm{~cm}^{-3}$. The highest $\mathrm{N}_{3-10}$ values are associated to air masses with enhanced $\mathrm{N}_{50}$. This effect of inhomogeneous air mass dispersion implies that sources of gas and particles might be local and close to the observation area. As the above NPF events (RF43, RF45) were localized upwind Rotterdam (150 km) and Amsterdam $(133 \mathrm{~km})$, the metropolises along the coast might be the sources of NPF events.

Moreover, $\mathrm{N}_{3-10}$ gradient and fluctuation decrease when the distance from the Netherland coastline increases (Fig. 3b and c). At $50 \mathrm{~km}$ away from the coastline of the Netherlands the $\mathrm{N}_{3-10}$ particle concentration averages $18000 \mathrm{~cm}^{-3}$ and at more than $130 \mathrm{~km}$ away from the coastline the $\mathrm{N}_{3-10}$ is lower than $10000 \mathrm{~cm}^{-3}$ (Fig. 3b). The gradient of $\mathrm{N}_{3-10}$ is more pronounced during the RF48. Indeed the $\mathrm{N}_{3-10}$ particle concentration reached $100000 \mathrm{~cm}^{-3}$ close to the coastline $(<30 \mathrm{~km})$ and was lower than $15000 \mathrm{~cm}^{-3}$ at more than $130 \mathrm{~km}$ from the coastline (Fig. 3c). The horizontal $\mathrm{N}_{3-10}$ gradient is a result of the air mass dispersion, as well as nucleation particle growth and coagulation of nucleation particles during the transport from their source to the observation area. The particle concentrations $\left(\mathrm{N}_{3}-10\right)$ were higher during the RF48 which might be due to the environmental differences (low tide and higher solar radiation). Besides these favourable NPF event conditions, during the RF48, the freshly nucleated particles were propagating deeply over the sea due to high surface wind speeds $\left(>10 \mathrm{~m} \mathrm{~s}^{-1}\right)$. Then the gradient intensity depends on the distance between the localization of the ultra-fine particle precursor sources and the observation area, and on the surface wind speed.

The Group II events were observed during two flights: RF43 on 5 May 2008 (Fig. 4a) and RF48 on 11 May 2008 (Fig. 4b). The uppermost limit of Group II events horizontal extension can not be determined with the observations $(>50 \mathrm{~km})$. The $\mathrm{N}_{3-10}$ were homogeneous $\left(\sim 80000 \mathrm{~cm}^{-3}\right)$ over the flight track at a constant level of pressure, but one can note that close or upwind to the big cities (Rotterdam and Eindhoven) the $\mathrm{N}_{3-10}$ decreased drastically to reach 

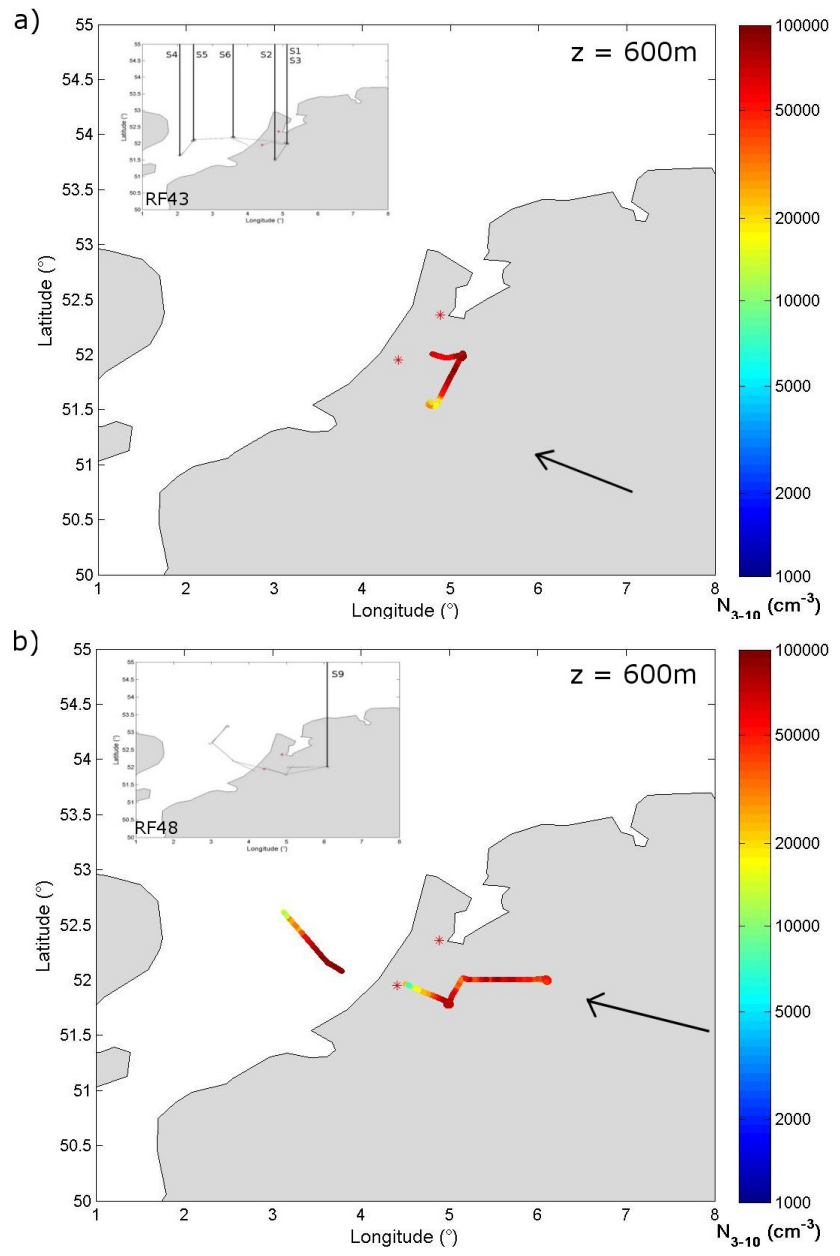

Fig. 4. As for Fig. 3 for Group II events (a) research flights RF43 on 5 May, and (b) RF48 on 11 May.

values lower than $20000 \mathrm{~cm}^{-3}$. This results is likely a consequence of highly polluted air masses above and downwind of cities enriched in particles $\left(\mathrm{N}_{50}\right)$ on which condensable vapours could condense. For both cases the $\mathrm{N}_{50}$ is higher than $4000 \mathrm{~cm}^{-3}$ in the vicinity of cities.

The Group III events were observed during two flights that have been performed on a single day: RF53 on 18 May 2008 during the morning (Fig. 5a) and RF54 on 18 May 2008 during the afternoon (Fig. 5b). Both research flights were performed nearby the Netherlands coastline. The air mass trajectories were similar all day long. Air masses originated from the Norway coast and, during their transport, never crossed a pollution plume. Thus, these air masses should have been enriched in organic vapours originating from volatile organic compounds (VOC) photo-oxidation from the Boreal forest and impoverished in particles $\left(<1000 \mathrm{~cm}^{-3}\right)$. These conditions are highly favourable for the occurrence of NPF events (Clarke et al., 1998; O’Dowd et al., 1998, 1999; Komppula et al., 2006; Metzger et al., 2010). In the morning, the NPF event was observed at lower altitudes of the BL
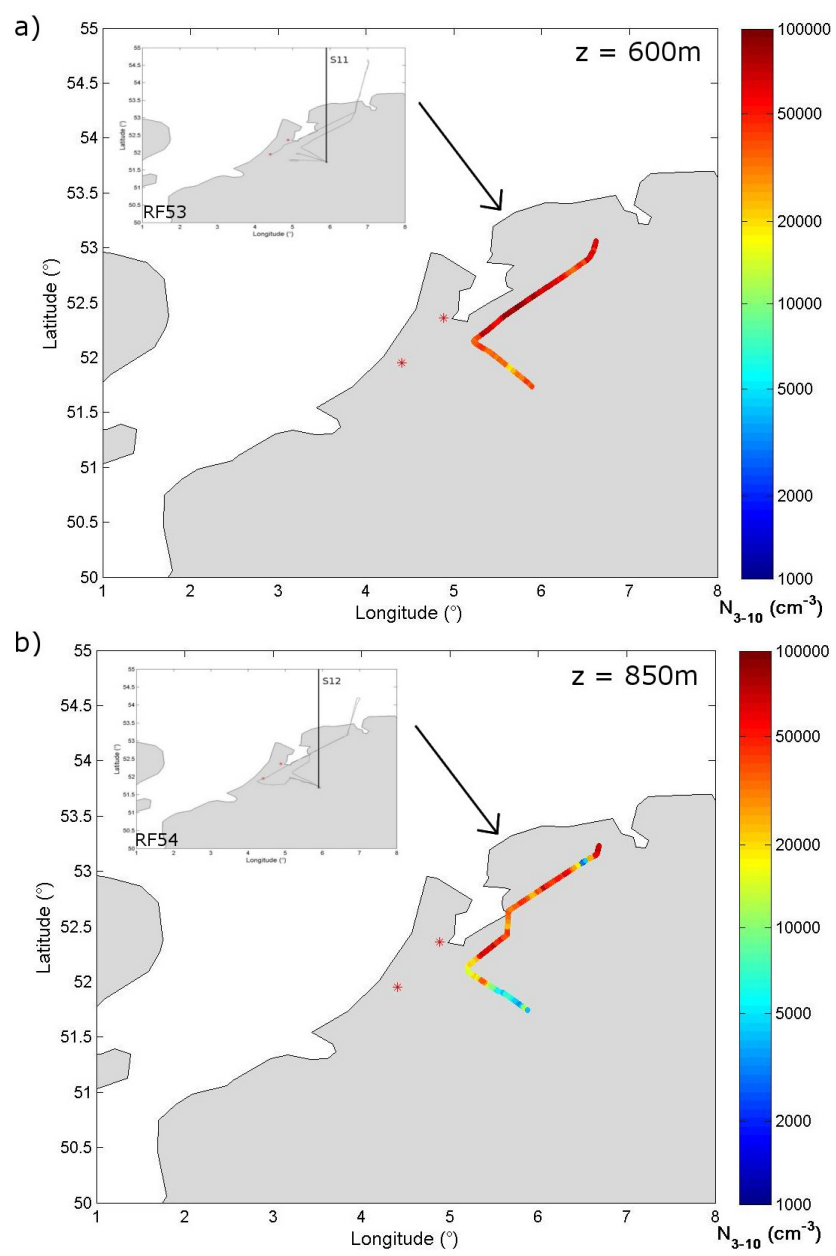

Fig. 5. As for Fig. 3 for Group III events (a) RF53 on 18 May and (b) RF54 on 18 May.

$(600 \mathrm{~m})$ between 5.2 and $6.7^{\circ} \mathrm{E} . \mathrm{N}_{3-10}$ concentrations have been around $52000 \mathrm{~cm}^{-3}$ over the entire leg (longitude: $5.2-$ $\left.6.2^{\circ} \mathrm{E}\right)$. During the afternoon, in the BL $(850 \mathrm{~m})$, the averaged $\mathrm{N}_{3-10}$ particle concentration was about $43000 \mathrm{~cm}^{-3}$ (longitude: $5.2-6.8^{\circ} \mathrm{E}$ ). The tide conditions were not the same during both flights, low tide in the morning and high tide in the early afternoon (Table 2). Thus, for these cases, the tide conditions may influence the intensity of the NPF event but not the fact that these events occurred. Upwind of Amsterdam and Rotterdam, the $\mathrm{N}_{50}$ concentration reached maximum values of $2000 \mathrm{~cm}^{-3}$. During both flights, the horizontal extension of the NPF events could not be delineated. Indeed, NPF events were spread over a distance larger than $200 \mathrm{~km}$. Despite of this large horizontal extension, the $\mathrm{N}_{3-10}$ was homogeneous during both flight segments (RF53 and RF54) close to the coastline. As there are many environmental differences between both flight (flight altitude, vertical dynamics), the comparison of $\mathrm{N}_{3-10}$ is not straightforward, however, the time evolution of the NPF event is demonstrated. Indeed $3 \mathrm{~h}$ after the NPF event (flight 53) 


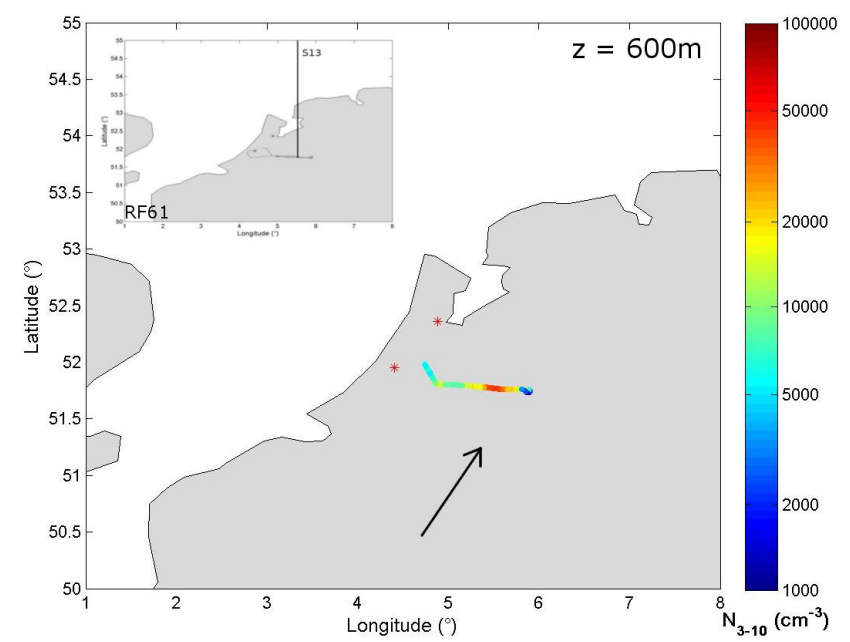

Fig. 6. As for Fig. 3 for research flight RF61 on 28 May (Group IV event).

sampled with the ATR-42, the phenomena is still persisting in the lower layer (flight 54). The SMPS measurements onboard the ATR-42 demonstrate nicely the temporal growth of nucleation particles (i) within each of the two flights and (ii) particularly when comparing flights. The observed modal diameter reached $30-35 \mathrm{~nm}$ in diameter towards the end of the afternoon flight.

Finally, the Group IV events were observed during RF61 on 28 May 2008 during the early afternoon (Fig. 6). As mentioned before, this event is different from all the others because of its localized character. Indeed, the longitudinal and vertical bounds of the NPF event are well determined during the flight $\left(5.1-5.8^{\circ} \mathrm{E}\right.$ and $\left.620-1350 \mathrm{~m}\right)$. The $\mathrm{N}_{3-10}$ heterogeneity along the flight segment was striking as compared to the Group I-III events. The $\mathrm{N}_{3-10}$ maximum values $\left(40000 \mathrm{~cm}^{-3}\right)$ were reached at $5.6^{\circ} \mathrm{E}$ and $51.8^{\circ} \mathrm{N}$. Over the leg the terrain has been similar, consisting of a succession of smallest towns/villages and arable farmland. Thus, localised sources of NPF precursors over the area of observed NPF events may have been insignificant, rather longer range transport into the area is the most likely source for NPF observations. Generally, the environmental conditions were totally different during the last five flights (RF59, RF60, RF61, RF62, RF63) as compared to the previous ones (particularly Groups I-III). Indeed, the air mass trajectories were coming from the south and then crossed many pollution plumes from industrialized regions of France and Germany. Along the whole flight track at $600 \mathrm{~m}$ of RF61, the $\mathrm{N}_{50}$ concentration was higher than $5000 \mathrm{~cm}^{-3}$ and reached $45000 \mathrm{~cm}^{-3}$ where the NPF event has been detected. Thus, this inhomogeneous case occurred under highly polluted conditions.

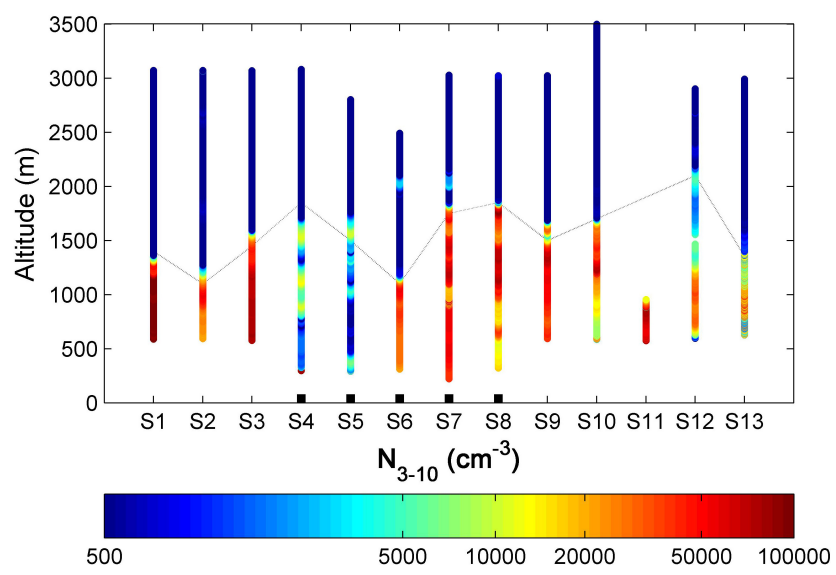

Fig. 7. Profile of the particle concentrations within the size range of 3-10 nm during the ATR-42 soundings for the six flights when NPF events were observed: RF43 (S1, S2, S3, S4, S5, S6) on 05 May, RF45 (S7, S8) on 08 May, RF48 (S9) on 11 May, RF50 (S10) on 14 May, RF53 (S11) on 18 May, RF54 (S12) on 18 May, and RF61 (S13) on 28 May 2008. The black rectangles highlight soundings performed above the sea. The grey line corresponds to the top of the BL as described in Table 3.

\subsubsection{Vertical extension}

During all presented ATR-42 flights, where nucleated particles have been observed, at least one vertical profiling has been made, either at the beginning or at the end of the flight between $0.3 \mathrm{~km}$ and $3.5 \mathrm{~km}$ (highest flight level), providing a rapid characterization of the vertical profiles of thermodynamic conditions (inversion level, etc.) and microphysical parameters. For each flight the height of the BL, determined by the vertical temperature and humidity progress, and the height of the NPF event, estimated by the $\mathrm{N}_{3-10}$, have been reported in Table 3 and represented in the Fig. 7. This table shows that, in our cases, NPF events appear to be initiated within the BL and to be limited by the top of the BL. The lower limit $(600 \mathrm{~m})$ of a NPF event has been observed only during the sounding S13 on 18 May. The comparison of soundings performed over the sea (S4, S5, S6, S7 and S8) and over the continent (all the others) shows no clear $\mathrm{N}_{3-10}$ vertical trends related to the surface differences. The NPF event observed over the sea during RF43 (S4 and S5) was only detected within the first $50 \mathrm{~m}$ of the soundings and the vertical exploration during S11 was not sufficient, thus, these three soundings will not be discussed hereafter.

Independently from the horizontal extension study, three different groups of soundings are defined: Group SI soundings (soundings S1, S3, and S9) corresponds to homogenous events throughout the PBL, Group SII soundings (S2, S6, S8 and S10) corresponds to positive vertical gradients of $\mathrm{N}_{3-10}$ with the altitude and Group SIII soundings (S12 and S13) corresponds to negative vertical gradients of $\mathrm{N}_{3-10}$ as a function of altitude. During the sounding S7, a special NPF event has been observed, thus S7 will be discussed separately. 
Table 3. Horizontal and vertical extension of all detected new particle formation (NPF) events. In addition to the vertical extension of NPF events is presented the top of the boundary layer (BL), both derived from numerous ATR-42 ascents and descents.

\begin{tabular}{cccccccc}
\hline $\begin{array}{c}\text { Flight } \\
\text { number }\end{array}$ & Soundings & $\begin{array}{c}\text { Sounding } \\
\text { start and } \\
\text { end times }\end{array}$ & $\begin{array}{c}\text { Sounding } \\
\text { zone } \\
(\mathrm{m})\end{array}$ & $\begin{array}{c}\text { BL } \\
\text { height } \\
\text { limit }(\mathrm{m})\end{array}$ & $\begin{array}{c}\text { NPF event } \\
\text { upper } \\
\text { limit }(\mathrm{m})\end{array}$ & $\begin{array}{c}\text { NPF event } \\
\text { lower } \\
(\mathrm{km})\end{array}$ & $\begin{array}{c}\text { Horizontal } \\
\text { extension }\end{array}$ \\
\hline & S1 & $11: 12-11: 31$ & Continent & 1400 & 1325 & - & $>100$ \\
& S2 & $11: 34-11: 51$ & Continent & 1100 & 1100 & - & \\
& S3 & $12: 03-12: 11$ & Continent & 1450 & 1550 & - & \\
& S4 & $12: 46-12: 56$ & North Sea & 1850 & 300 & - & \\
& S5 & $13: 08-13: 24$ & North Sea & 1500 & 300 & - & \\
& S6 & $13: 48-14: 03$ & North Sea & 1100 & 1100 & - & \\
& S7 & $11: 54-12: 09$ & North Sea & 1750 & 1800 & - & $>100$ \\
45 & S8 & $13: 11-13: 29$ & North Sea & 1850 & 1850 & - & \\
\hline 48 & S9 & $10: 29-10: 49$ & Continent & 1500 & 1450 & - & $>160$ \\
50 & S10 & $12: 16-12: 55$ & Continent & 1700 & 1650 & - & $>70$ \\
53 & S11 & $08: 30-09: 20$ & Continent & 1900 & 1080 & - & $>150$ \\
54 & S12 & $12: 01-12: 11$ & Continent & 2100 & 2100 & 600 & $>150$ \\
61 & S13 & $13: 40-14: 30$ & Continent & 1350 & 1400 & - & $\sim 100$ \\
\hline
\end{tabular}

The observed meteorological and environmental conditions (air mass origins, temperature, pressure, wind speed, solar radiation) were somewhat similar during Group SI and Group SII soundings. In contrast, both observed soundings with negative vertical gradients of $\mathrm{N}_{3-10}$ (Group SIII) were observed after rain events $(>0.8 \mathrm{~mm})$, thus related to potential scavenging of aerosol particles and to potential entrainment of pollutant into the lower atmospheric layers. Moreover, the prevailing air mass trajectories, in the BL, of the Group I and Group II soundings were similar and came from South-East while Group III trajectories came from NorthEast (clean marine air, S12) and South-West (polluted air, S13). Thus, after rainy events, a nucleation event was observed whatever the pollution level of the air mass. Moreover, one can note that the negative vertical gradients were not well-marked compare to the positive ones.

Within the frame of the small number of aircraft soundings performed during the EUCAARI campaign, when nucleation particles have been observed, the classification in different groups yields, that the frequency of positive vertical gradient of $\mathrm{N}_{3-10}$ is higher than the frequency of observed negative gradients, which would mean that nucleated particles are likely to be increased more frequently in the upper part of the BL. Two processes may explain the presence of ultra-fine particles in this altitude range: (1) particles have been nucleated at the ground and then uplifted before being sampled with the ATR-42 and (2) particles have been nucleated in the upper part of the BL.

To understand which process has been involved in our cases, we first assume that particles have been formed at the ground, calculate the mean diameter that particles should have after being uplifted into the upper part of the BL and compare their mean diameter with the observations. Following the work of Hirsikko et al. (2005), the temporal evolution of ion size distributions, measured with the NAIS instrument at the CBW station, has been utilized to estimate growth rates of newly formed particle populations. To accomplish this estimation, lognormal distributions were fitted to the NAIS size distributions (including the ultra-fine particle mode) as a function of time. After determining the mean diameters corresponding to the peak concentrations in the lognormally fitted ultra-fine mode, the growth rates were obtained by a linear fit through the data points of peak concentrations in that mode with time (Hirsikko et al., 2005). We calculated the growth rates in $\mathrm{nm}$ per hour, applying linear fits within following size ranges: 1.5 to 3,3 to 7 and 7 to $20 \mathrm{~nm}$ (Table 3).

The three resulting growth rates for the above size ranges vary from day to day. The total diameter increase $(\Delta D p)$ is then calculated during vertical transport from the ground to the upper limit of the NPF event, assuming that particle growth rates are similar to the growth rates determined for the measurements at the Cabauw site (Table 4). The time which is needed for freshly formed particles to reach altitudes that has been found by this study to be the upper altitude limit of NPF events has been determined using the observed vertical wind velocity data $(W)$. The mean diameter of uplifted particles have been calculated with the total diameter increase plus initial diameter estimated at $1 \mathrm{~nm}$. For three cases (RF50 RF53 and RF54), particles assumed having been newly formed at the ground and vertically transported to the upper limit of the NPF event, have a mean diameter lower than $10 \mathrm{~nm}$ at this upper limit which is consistent with the observed nucleation particles diameter. Thus, for these two 
Table 4. Mean vertical component of the wind $\left(W, \mathrm{~m} \mathrm{~s}^{-1}\right)$ observed during all detected new particle formation (NPF) events. The estimated median growth rates for nucleation mode charged particles in size ranges 1.5-3, 3-7 and 7-20 nm. Calculations are based on ion size distributions measured at the Cabauw field site during the flights. Estimation of the minimum diameter increase $(\Delta D p)$ assuming that the particle is formed at the surface site and is transported to the top of the boundary layer. Thus, $\Delta D p$ is calculated using the growth rate, estimated with the NAIS measurements at the Cabauw field site, the mean vertical wind speed $(W)$ observed in the BL and the height of the $\mathrm{BL}$ given in Table $2(\Delta D p=\mathrm{GR} \cdot W \cdot \mathrm{BL})$.

\begin{tabular}{ccccccc}
\hline Date & $\begin{array}{c}\text { Flight } \\
\text { number }\end{array}$ & $W\left(\mathrm{~m} \mathrm{~s}^{-1}\right)$ & $\begin{array}{c}\text { GR median } \\
1.5-3 \mathrm{~nm} \\
(\mathrm{~nm} / \mathrm{h})\end{array}$ & $\begin{array}{c}\text { GR median } \\
3-7 \mathrm{~nm} \\
(\mathrm{~nm} / \mathrm{h})\end{array}$ & $\begin{array}{c}\text { GR median } \\
7-20 \mathrm{~nm} \\
(\mathrm{~nm} / \mathrm{h})\end{array}$ & $\Delta D p(\mathrm{~nm})$ \\
\hline 5 May 2008 & 43 & 0.0155 & 3.94 & 10.64 & 7.37 & $204.5 \pm 2.5$ \\
8 May 2008 & 45 & 0.1572 & 5.92 & 6.94 & 5.93 & $19.9 \pm 2$ \\
11 May 2008 & 48 & 0.0288 & 3.04 & 3.32 & 5.12 & $68.5 \pm 1.5$ \\
14 May 2008 & 50 & 0.5362 & 6.54 & 7.58 & 6.99 & $6.2 \pm 2.1$ \\
18 May 2008 & 53 & 0.4314 & 2.40 & 7.99 & 13.06 & $2.2 \pm 1.8$ \\
18 May 2008 & 54 & 0.4614 & 2.40 & 7.99 & 13.06 & $7.3 \pm 5.2$ \\
28 May 2008 & 61 & 0.3811 & 7.17 & 21.82 & 14.25 & $14.5 \pm 3.5$ \\
\hline
\end{tabular}

cases we cannot rule out that $\mathrm{N}_{3-10}$ particle concentrations observed at $1650 \mathrm{~m}$ and $1100 \mathrm{~m}$, respectively, might have been solely due to transport of NPF events originating at the ground. However, for at least the other four cases the exclusive transport of freshly formed particles from the surface to higher altitudes cannot be inferred from these considerations. Indeed, the mean diameter of uplifted particles is higher than $10 \mathrm{~nm}$ thus higher than the observed particle diameter. These latter NPF events have not been limited to the ground, but should have originated from elsewhere in the BL.

During sounding 7, the $\mathrm{N}_{3-10}$ concentration abruptly decreased $\left(20000 \mathrm{~cm}^{-3}\right)$ in a sub-layer of the BL between $950 \mathrm{~m}$ and $1100 \mathrm{~m}$. This particular stratification is related to the presence of two different layers in terms of pre-existing particle concentrations $\left(\mathrm{N}_{50}\right)$. Whereas in the lower part of the BL $(200 \mathrm{~m}<z<950 \mathrm{~m}), \mathrm{N}_{50}$ is homogeneous and lower than $1000 \mathrm{~cm}^{-3}$, in the upper part of the BL $(950 \mathrm{~m}<z<$ $1800 \mathrm{~m}$ ) the $\mathrm{N}_{50}$ concentration reached $5000 \mathrm{~cm}^{-3}$. Thus, this sounding illustrates two different NPF events: the first one under almost clean conditions and the second one under polluted conditions.

\section{Conclusions}

This paper describes six cases of new particle formation (NPF) events observed on board the ATR-42 research aircraft during the EUCAARI intensive measurement campaign in May 2008. All these events were observed at different moments of the day, stages of development and locations (both marine and continental). An extended air mass backtrajectory analysis highlights that the most of air masses in the boundary layer that have been observed during the campaign are coming from the North Sea and Scandinavia. The probability, associated with these air masses, to observe a NPF event with the ATR-42 is in average about $40 \%$ and $60 \%$ respectively. The transport of clean air masses from the North Sea, which are enriched in sulphate and organic components, to Cabauw (CBW) may have an influence on NPF event over the Netherlands (Kulmala et al., 2001; Kulmala et al., 2004b; Komppula et al., 2006; Tunved et al., 2006).

As the nucleation phenomenon was not the major focus of the ATR-42 flights during EUCAARI, the ATR-42 flight plans were not performed with the objective to horizontally bound the NPF events, and therefore ATR-42 results presented here provide a best estimate of the horizontal extension $(>70 \mathrm{~km})$ of NPF area. Moreover, the highest particle concentrations in the size range $3-10 \mathrm{~nm}\left(\mathrm{~N}_{3-10}, 10^{5} \mathrm{~cm}^{-3}\right)$ were observed over the continent whereas the lowest nucleation mode particle concentrations $\left(<5000 \mathrm{~cm}^{-3}\right)$ were observed over the North Sea. These limiting cases were observed during the same flight (on 5 May). As the $\mathrm{N}_{3-10}$ is highly variable during these six NPF events, four types of NPF event groups (Group I-IV) were defined as a function of air mass origin and geographical location of performed flights. All events observed over the sea (Group I) were related to continental flow regimes. These observations highlight a negative gradient of $\mathrm{N}_{3-10}$ from the coastline further to the North Sea. The intensity of the gradient appears to be dependant of the tide conditions and low level ( $<900$ mbar) wind speeds. Over the continent, the $\mathrm{N}_{3-10}$ are homogeneous along five flight tracks. One inhomogeneous case is observed during research flight 61 (Group IV events) which were observed under highly polluted conditions. Close or upwind to big cities the number concentration of pre-existent particles greater than $50 \mathrm{~nm}$ diameter $\left(\mathrm{N}_{50}\right)$ is important and inhibits the nucleation process. 
During the numerous ascents and descents of the ATR-42, the vertical extension of the NPF events did not exceed the top of the BL and no NPF event was detected in the free troposphere. These results have also been observed for boreal nucleation events (Laaksonen et al., 2008; O'Dowd et al., 2009). Over the continent as well as over the North Sea, the vertical extension of NPF events seems to coincide exactly with the top of the BL for most of the observed cases. Three different types of soundings have been observed: homogeneous (Group SI; three soundings), positive vertical (increasing with altitude) $\mathrm{N}_{3-10}$ gradient (Group SII; four soundings) and negative vertical (decreasing with altitude) $\mathrm{N}_{3-10}$ gradient (Group SIII; two soundings). The frequency of NPF event occurrences in the higher part of the BL is important (number of positive vertical gradients) as already observed by Venzac et al. (2009). Based on the hypothesis that particles may have been nucleated solely at the surface, then transported to higher levels within the BL, particle growth rates have been estimated from simultaneous nucleation findings at the CBW ground station. We conclude that most of the nucleated particle events observed with the ATR- 42 have not been formed at the surface but must have nucleated elsewhere in the BL.

This work demonstrates that NPF events observed during ATR-42 flights within EUCAARI have been limited to the top of the boundary layer but showed differences in terms of horizontal and vertical homogeneity and extension. Newly formed particles evolve to larger sizes within hours, which impacts the energy budget and through direct radiative forcing and aerosol-cloud interactions. Airborne measurements of NPF at different locations around the world would help constrain vertical and horizontal scales allowing better implementation of the nucleation phenomenon to be implemented in existing global model studies (Spracklen et al., 2008; Makkonen et al., 2009).

Acknowledgements. This work has been partially funded by European Commission 6th Framework program project EUCAARI, contract no. 036833-2 (EUCAARI), and by the French National Research Agency (ANR) under the AEROCLOUD program, contract no 06-BLAN-0209. Suzanne Crumeyrolle has been supported by CNRS fellowship (contract no. 167641). The authors gratefully acknowledge the NOAA Air Resources Laboratory (ARL) for the provision of the HYSPLIT transport and dispersion model and/or READY website (http://www.arl.noaa.gov/ready.html) used in this publication. The authors wish to thank the SAFIRE (Service des Avions Français Instruments pour la Recherche en Environnement) for preparing and delivering the research aircraft (ATR-42). They also want to thank the SHOM (Service Hydrographique et Océanographique de la Marine) for the availability of the height tide data.

Edited by: V.-M. Kerminen

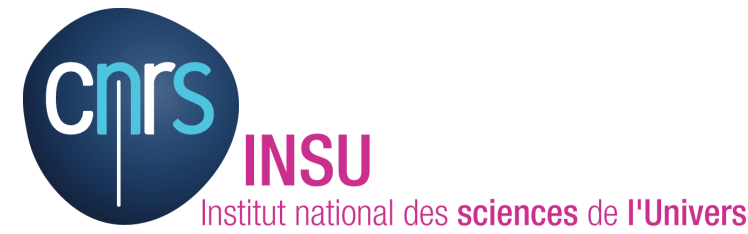

The publication of this article is financed by CNRS-INSU.

\section{References}

Adams, P. J. and Seinfeld, J. H.: Predicting global aerosol size distributions in general circulation models, J. Geophys. Res., 107(D19), 4370, doi:10.1029/2001JD001010, 2002.

Birmili, W. and Wiedensohler, A.: New particle formation in the continental boundary layer: Meteorological and gas phase parameter influence, Geophys. Res. Lett., 27, 3325-3328, 2000.

Birmili W., Wiedensholer, A., Heintzenberg, J., and Lehmann, K.: Atmospheric particle number size distribution in central europe: statistical relations to air masses and meteorology, J. Geophys. Res., 106(D23), 32005-32018, 2001.

Bond, T., Anderson, C., and Campbell, T. L. D. : Calibration and Intercomparison of Filter-Based Measurements of Visible Light Absorption by Aerosols, Aerosol Sci. Tech, 30(6), 582600, doi:10.1080/027868299304435, 1999.

Brenguier, J. L., Bourrianne, T., Coelho, A., Isbert, J., Peytavi, R., Trevarin, D., and Wechsler, P.: Improvements of droplet size distribution measurements with the Fast-FSSP, J. Atmos. Oceanic. Technol., 15, 1077-1090, 1998.

Brock, C. A., Hamill, P., Wilson, J. C., Jonsson, H. H., and Chan, K. R.: Particle formation in the upper Tropical Troposphere: A source of nuclei for the stratospheric aerosol, Science, 270, 1650-1653, 1995.

Canagaratna, M. R., Jayne, J. T., Jimenez, J. L., Allan, J. D., Alfarra, M. R., Zhang, Q., Onasch, T. B., Drewnick, F., Coe, H., Middlebrook, A., Delia, A., Williams, L. R., Trimborn, A. M., Northway, M. J., DeCarlo, P. F., Kolb, C. E., Davidovits, P., and Worsnop, D. R.: Chemical and Microphysical Characterization of Ambient Aerosols with the Aerodyne Aerosol Mass Spectrometer, Mass Spectrom. Rev., 26, 185-222, 2007.

Carpenter, L. J., Sturges, W. T., Penkett, S. A., Liss, P. S., Alicke, B., Hebestreit, K., and Platt, U.: Short-lived alkyl iodides and bromides at Mace Head, Ireland, J. Geophys. Res., 104, 16791689, 1999.

Carpenter, L. J., Malin, G., Küpper, F. C., and Liss, P. S.: Novel biogenic iodine-containing trihalomethanes and other short-lived halocarbons in the coastal East Atlantic, Global Biogeochem. Cy., 14, 1191-1204, 2000.

Clarke, A. D., Varner, J. L., Eisele, F., Mauldin, R. L., Tanner, D., and Litchy, M.: Particle production in the remote marine atmosphere: cloud outflow and subsidence during ACE 1, J. Geophys. Res., 103, 16397-16409, 1998.

Curtius, J., Lovejoy, E. R., and Froyd, K. D.: Atmospheric ioninduced aerosol nucleation, Space Sci. Rev., 125(1-4), 159-167, 2006.

Crumeyrolle, S., Gomes, L., Tulet, P., Matsuki, A., Schwarzenboeck, A., and Crahan, K.: Increase of the aerosol hygroscopicity by cloud processing in a mesoscale convective system: a 
case study from the AMMA campaign, Atmos. Chem. Phys., 8, 6907-6924, doi:10.5194/acp-8-6907-2008, 2008.

Dal Maso M., Sogacheva, L., Anisimov, M. P., Arshinov, M., Baklanov, A., Belan, B., Khodzher, T. V., Obolkin, V. A., Staroverova, A., Vlasov, A., Zagaynov, V. A., Lushnikov, A., Lyubovtseva, Y. S., Riipinen, I., Kerminen, V. M., and Kulmala, M.: Aerosol particle formation events at two Siberian stations inside the boreal forest, Boreal Environ. Res., 13, 81-92, 2008.

Dal Maso, M., Kulmala, M., Riipinen, I., Wagner, R., Hussein, T., Aalto, P. P., and Lehtinen, K. E. J.: Formation and growth of fresh atmospheric aerosols: eight years of aerosol size distribution data from SMEAR II, Hyytiälä, Finland, Boreal Environ. Res., 10, 323-336, 2005.

Drewnick, F., Hings, S. S., DeCarlo, P. F., Jayne, J. T., Gonin, M., Fuhrer, K., Weimer, S., Jimenez, J. L., Demerjian, K. L., Borrmann, S., Worsnop, D. R.: A new Time-of-Flight Aerosol Mass Spectrometer (ToF-AMS) - Instrument Description and First Field Deployment, Aerosol Sci. Tech., 39, 637-658, 2005.

Draxler, R. R. and Rolph, G. D.: HYSPLIT (HYbrid Single-Particle Lagrangian Integrated Trajectory) Model access via NOAA ARL READY Website (http://www.arl.noaa.gov/ready/hysplit4.html), NOAA Air Resources Laboratory, Silver Spring, MD, 2003.

Ganguly, D., Jayaraman, A., and Gadhavi, H.: Physical and optical properties of aerosols over an urban location in western India: Seasonal variabilities, J. Geophys. Res. Atmos., 111(D24), D24206, doi:10.1029/2006JD007392, 2006.

Hirsikko, A., Laakso, L., Hõrrak, U., Aalto, P. P., Kerminen, V.M., and Kulmala, M.: Annual and size dependent variation of growth rates and ion concentrations in boreal forest, Boreal Env. Res., 10, 357-369, 2005.

Hussein, T., Martikainen, J., Junninen, H., Sogacheva, L., Wagner, R., Dal Maso, M., Riipinen, I., Aalto, P. P., and Kulmala, M.: Observation of regional new particle formation in the urban atmosphere, Tellus, 60B, 509-521, 2008.

IPCC: Intergovernmental Panel on Climate Change, ClimateChange 2007 - The Physical Science Basis: Contribution ofWorking Group I to the Fourth Assessment Report of the IPCC, Cambridge, Cambridge University Press, 2007.

Jayne, J. T., Leard, D. C., Zhang, X., Davidovits, P., Smith, K. A., Kolb, C. E., and Worsnop, D. R.: Development of an Aerosol Mass Spectrometer for Size and Composition Analysis of Submicron Particles, Aerosol Sci. Tech., 33, 49-70, 2000.

Jokinen, V. and Mäkelä, J: Closed loop arrangement with critical orifice for DMA sheath/excess fl ow system, J. Aerosol Sci., 28, 643-648, 1996.

Junge, C. E., Chagnon, C. W., and Manson, J. E.: A world-wide stratospheric aerosol layer, Science, 133, 1478-1479, 1961.

Kaufman, Y. J., Tanre, D., and Boucher, O.: A satellite view of aerosols in the climate system, Nature, 419, 215-223, 2002.

Kerminen, V.-M., Pirjola, L., and Kulmala, M.: How significantly does coagulational scavenging limit atmospheric particle production?, J. Geophys. Res., 106, 24119-24126, 2001.

Komppula, M., Sihto, S.-L., Korhonen, H., Lihavainen, H., Kerminen, V.-M., Kulmala, M., and Viisanen, Y.: New particle formation in air mass transported between two measurement sites in Northern Finland, Atmos. Chem. Phys., 6, 2811-2824, doi:10.5194/acp-6-2811-2006, 2006.

Kuang, C., Mc Murry, P. H., McCormick, A. V., and Eisele, F. L.: Dependence of nucleation rates on sulphuric acid vapour concen- tration in diverse atmospheric locations, J. Geophys. Res., 113, D10209, doi:10.1029/2007JD009253, 2008.

Kulmala, M., Dal Maso, M., Mäkelä, J. M., Pirjola, L., Väkevä, M., Aalto, P., Miikkulainen, P., Hämmeri, K., and O'Dowd, C.: On the formation, growth and composition of nucleation mode particles, Tellus, 53B, 479-490, 2001.

Kulmala, M.: How Particles Nucleate and Grow, Science, 302, 1000-1001, 2003.

Kulmala, M., Vehkamäki, H., Petäjä, T., Dal Maso, M., Lauri, A., Kerminen, V.-M., Birmili, W., and McMurry, P. H.: Formation and growth rates of ultrafine atmospheric particles: A review of observations, J. Aerosol Sci., 35, 143-176, 2004a.

Kulmala, M., Suni, T., Lehtinen, K. E. J., Dal Maso, M., Boy, M., Reissell, A., Rannik, Ü., Aalto, P., Keronen, P., Hakola, H., Bäck, J., Hoffmann, T., Vesala, T., and Hari, P.: A new feedback mechanism linking forests, aerosols, and climate, Atmos. Chem. Phys., 4, 557-562, doi:10.5194/acp-4-557-2004, 2004.

Kulmala, M., Riipinen, I., Sipilä, M., Manninen, H., Petäjä, T., Junninen H., Dal Maso, M., Mordas, G., Mirme, A., Vana, M., Hirsikko, A., Laakso, L., Harrison, R. M., Hanson, I., Leung, C., Lehtinen, K. E. J., and Kerminen, V.-M.: Towards direct measurement of atmospheric nucleation, Science, 318, 89-92, doi:10.1126/science.1144124, 2007.

Kulmala, M. and Kerminen, V.-M.: On the growth of atmospheric nanoparticles, Atmos. Res., 90, 132-150, 2008.

Kulmala, M., Asmi, A., Lappalainen, H. K., Carslaw, K. S., Pöschl, U., Baltensperger, U., Hov, /O., Brenquier, J.-L., Pandis, S. N., Facchini, M. C., Hansson, H.-C., Wiedensohler, A., and O'Dowd, C. D.: Introduction: European Integrated Project on Aerosol Cloud Climate and Air Quality interactions (EUCAARI) - integrating aerosol research from nano to global scales, Atmos. Chem. Phys., 9, 2825-2841, doi:10.5194/acp-9-2825-2009, 2009.

Laaksonen, A., Kulmala, M., O’Dowd, C. D., Joutsensaari, J., Vaattovaara, P., Mikkonen, S., Lehtinen, K. E. J., Sogacheva, L., Dal Maso, M., Aalto, P., Petäjä, T., Sogachev, A., Yoon, Y. J., Lihavainen, H., Nilsson, D., Facchini, M. C., Cavalli, F., Fuzzi, S., Hoffmann, T., Arnold, F., Hanke, M., Sellegri, K., Umann, B., Junkermann, W., Coe, H., Allan, J. D., Alfarra, M. R., Worsnop, D. R., Riekkola, M. -L., Hyötyläinen, T., and Viisanen, Y.: The role of VOC oxidation products in continental new particle formation, Atmos. Chem. Phys., 8, 2657-2665, doi:10.5194/acp-82657-2008, 2008.

Laturnus F., Giese, B., Wiencke, C., and Adams, F. C.: Lowmolecular-weight organoiodine and organobromine compounds released by polar macroalgae - The influence of abiotic factors, J. Anal. Chem.+, 368, 297-302, 2000.

Lonati, G. and Giugliano, M.: Size distribution of atmospheric particulate matter at trafffic exposed sites in the urban area of Milan (Italy), Atmos. Environ., 40, S264-S274, Suppl. 2, 2006.

Mäkelä, J. M., Aalto, P., Jokinen, V., Pohja, T., Nissinen, A., Palmroth, S., Markkanen, T., Seitsonen, K., Lihavainen, H., and Kulmala, M.: Observations of ultrafine aerosol particle formation and growth in boreal forest, Geophys. Res. Lett., 24, 1219-1222, 1997.

Makkonen, R., Asmi, A., Korhonen, H., Kokkola, H., Järvenoja, S., Räisänen, P., Lehtinen, K. E. J., Laaksonen, A., Kerminen, V.M., Järvinen, H., Lohmann, U., Bennartz, R., Feichter, J., and Kulmala, M.: Sensitivity of aerosol concentrations and cloud 
properties to nucleation and secondary organic distribution in ECHAM5-HAM global circulation model, Atmos. Chem. Phys., 9, 1747-1766, doi:10.5194/acp-9-1747-2009, 2009.

Manninen, H. E., Petäjä, T., Asmi, E., Riipinen, I., Nieminen, T., Mikkilä, J., Hõrrak, U., Mirme, A., Mirme, S., Laakso, L., Kerminen, V.-M., and Kulmala, M.: Long-term field measurements of charged and neutral clusters using Neutral cluster and Air Ion Spectrometer (NAIS), Boreal Env. Res., 14, 591-605, 2009.

Matsuki, A., Schwarzenboeck, A., Venzac, H., Laj, P., Crumeyrolle, S., and Gomes, L.: Cloud processing of mineral dust: direct comparison of cloud residual and clear sky particles during AMMA aircraft campaign in summer 2006, Atmos. Chem. Phys., 10, 1057-1069, doi:10.5194/acp-10-1057-2010, 2010.

McMurry, P. H.: The History of CPCs, Aerosol Sci. Technol., 33, 297-322, 2000.

Mertes, S., Schrooder, F., and Wiedensohler, A.: The particle detection efficiency curve of the TSI3010 CPC as a function of temperature difference between saturator and condenser, Aerosol Sci. Tech., 23, 257-270, 1995.

McNaughton, C. S., Clarke, A. D., Howell, S. G., Pinkerton, M., Anderson, B., Hornhill, L. T., Hudgins, C., Winstead, E., Dibb, J. E., Sceuer, E., and Maring, H.:Results from the DC-8 Inlet Characterization Experiment (DICE): Airborne Versus Surface Sampling of Mineral Dust and Sea Salt Aerosols, Aerosol Sci. Tech., 41, 136-159, 2007.

Metzger,A., Verheggen, B., Dommen, J., Duplissy, J., Prevot, A. S. H., Weingartner, E., Riipinen, I., Kulmala, M., Spracklen, D. V., Carslaw, K. S., and Baltensperger, U.: Evidence for the role of organics in aerosol particle formation under atmospheric conditions, PNAS, 107(15), 6646-6651, doi:10.1073/pnas.0911330107, 2010.

Meskhidze, N., Remer, L. A., Platnick, S., Negrón Juárez, R., Lichtenberger, A. M., and Aiyyer, A. R.: Exploring the differences in cloud properties observed by the Terra and Aqua MODIS Sensors, Atmos. Chem. Phys., 9, 3461-3475, doi:10.5194/acp-93461-2009, 2009.

Mirme, S., Mirme, A., Minikin, A., Petzold, A., Hõrrak, U., Kerminen, V. -M., and Kulmala, M.: Atmospheric sub-3 nm particles at high altitudes, Atmos. Chem. Phys., 10, 437-451, doi:10.5194/acp-10-437-2010, 2010.

O’Dowd, C. D., Geever, M., Hill, M. K., Jennings, S. G., and Smith, M. H.: New particle formation: Spatial scales and nucleation rates in the coastal environment, Geophys. Res. Lett., 25, 16611664, 1998.

O’Dowd, C. D., McFiggens, G., Pirjola, L., Creasey, D. J., Hoell, C., Smith, M. H., Allen, B., Plane, J. M. C., Heard, D. E., Lee, J. D., Pilling, M. J., and Kulmala, M.: On the photochemical production of new particles in the coastal boundary layer, Geophys. Res. Lett., 26, 1707-1710, 1999.

O’Dowd, C. D., Becker, E., and Kulmala, M.: Mid-latitude North Atlantic aerosol characteristics in clean and polluted air, Atmos. Res., 58, 167-185, 2001.

O’Dowd, C. D., Hämeri, K., Mäkelä, J. M., Pirjola, L., Kulmala, M., Jennings, S. G., Berresheim, H., Hansson, H.-C., de Leeuw, G., Kunz, G. J., Allen, A. G., Hewitt, C. N., Jackson, A., Viisanen, Y., and Hoffmann, T.: A dedicated study of New Particle Formation and Fate in the Coastal Environment (PARFORCE): Overview of objectives and achievements, J. Geophys. Res., 107(D19), 8108, doi:10.1029/2001000555, 2002a.
O’Dowd, C. D., Hämeri, K., Mäkelä, J. M., Väkeva, M., Aalto, P., de Leeuw, G., Kunz, G. J., Becker, E., Hansson, H.-C., Allen, A. G., Harrison, R. M., Berresheim, H., Kleefeld, C., Geever, M., Jennings, S. G., and Kulmala, M.: Coastal new particle formation: Environmental conditions and aerosol physicochemical characteristics during nucleation bursts, J. Geophys. Res., 107(D19), 8107, doi:10.1029/2000JD000206, 2002b.

O’Dowd, C. D., Yoon, Y. J., Junkerman, W., Aalto, P., Kulmala, M., Lihavainen, H., and Viisanen, Y.: Airborne measurements of nucleation mode particles I: coastal nucleation and growth rates, Atmos. Chem. Phys., 7, 1491-1501, doi:10.5194/acp-71491-2007, 2007.

O’Dowd, C. D., Yoon, Y. J., Junkermann, W., Aalto, P., Kulmala, M., Lihavainen, H., and Viisanen, Y.: Airborne measurements of nucleation mode particles II: boreal forest nucleation events, Atmos. Chem. Phys., 9, 937-944, doi:10.5194/acp-9-937-2009, 2009.

Philippin, S., Laj, P., Putaud, J.-P., Wiedensohler A., de Leeuw G., Fjaeraa, A. M., Platt, U., Baltensperger U., and Fiebig, M.: EUSAAR - An Unprecedented Network of Aerosol Observation in Europe, Earozoru Kenkyu, JAAST, 24(2), 78-83, 2009.

Rodriguez, S., VanDingenen, R., Putaud, J. P., Martins-DosSantos, S., and Roselli, D.: Nucleation and growth of new particles in the rural atmosphere of Northern Italy - relationship to air quality monitoring, Atmos. Environ., 39(36), 6734-6746, 2005.

Schwarzenboeck, A., Heintzenberg, J., and Mertes, M.: Incorporation of aerosol particles between 25 and $850 \mathrm{~nm}$ into cloud elements: measurements with a new complementary sampling system, Atmos. Res., 52, 241-260, 2000.

Sogacheva, L., Dal Maso, M., Kerminen, V.-M., and Kulmala, M.: Probability of nucleation events and aerosol particle concentration in different air mass types arriving at Hyytiälä, southern Finland, based on back trajectory analysis, Boreal Environ. Res., 10, 479-491, 2005.

Sogacheva, L., Hamed, A., Facchini, M. C., Kulmala, M., and Laaksonen, A.: Relation of air mass history to nucleation events in Po Valley, Italy, using back trajectories analysis, Atmos. Chem. Phys., 7, 839-853, doi:10.5194/acp-7-839-2007, 2007.

Spichtinger, P. and Cziczo, D. J.: Aerosol-cloud interactions - a challenge for measurements and modeling at the cutting edge of cloud - climate interactions, Environ. Res. Lett., 3(2), 025002, doi:10.1088/1748-9326/3/2/025002, 2008.

Spracklen, D., Carslaw, K., Kulmala, M., Kerminen, V., Sihto, S., Riipinen, I., Merikanto, J., Mann, G., Chipperfield, M., Wiedensohler, A., et al.: Contribution of particle formation to global cloud condensation nuclei concentrations, Geophys. Res. Lett., 35, L06808, doi:10.1029/2007GL033038, 2008.

Stoltzenburg, M. R. and McMurry, P. H.: An ultrafine aerosol condensation nucleus counter, Aerosol Sci. Tech.,14, 48-65, 1991.

Tuch, T. M., Herbarth, O., Franck, U., Peters, A., Wehner, B., Wiedensohler, A., and Heintzenberg, J.: Weak correlation of ultrafine aerosol particle concentrations $<800 \mathrm{~nm}$ between two sites within one city, J. Expo. Sci. Env. Epid., 16(6), 486-490, 2006.

Tunved, P., Nilson, E. D., Hansson, H.-C., Ström, J., Kulmala, M., Aalto, P., and Viisanen, Y.: Aerosol characteristics of air masses in northern Europe: influences of location, transport, sinks, and sources, J. Geophys. Res, 110, D07201, doi:10.1029/2004JD0005085, 2005. 
Tunved, P., Hansson, H.-C., Kerminen, V.-M., Ström, J., Dal Maso, M., Lihavainen, H., Viisanen, Y., Aalto, P. P., Komppula, M., and Kulmala, M.: High Natural Aerosol Loading over Boreal Forests, Science, 312(5771), 261-263, 2006.

Van Ulden, A. P. and Wieringa, J.: Atmospheric boundary layer research at Cabauw, Bound.-Lay. Meteorol., 78, 39-69, 1996.

Vehkamäki, H., Dal Maso, M., Hussein, T., Flanagan, R., Hyvärinen, A., Lauros, J., Merikanto, P., Mönkkönen, M., Pihlatie, K., Salminen, K., Sogacheva, L., Thum, T., Ruuskanen, T. M., Keronen, P., Aalto, P. P., Hari, P., Lehtinen, K. E. J., Rannik, $\ddot{U}$, and Kulmala, M.: Atmospheric particle formation events at Värrió measurement station in Finnish Lapland 1998-2002, Atmos. Chem. Phys., 4, 2015-2023, doi:10.5194/acp-4-2015-2004, 2004.

Venzac, H., Sellegri, K., Villani, P., Picard, D., and Laj, P.: Seasonal variation of aerosol size distributions in the free troposphere and residual layer at the puy de Dôme station, France, Atmos. Chem. Phys., 9, 1465-1478, doi:10.5194/acp-9-1465-2009, 2009.

Venzac, H., Sellegri, K., Laj, P., Villani, P., Bonasoni, P., Marinoni, A., Cristofanelli, P., Calzolari, F., Fuzzi, S., Decesari, S., Facchini, M.-Cr., Vuillermoz, E., and Verza, G. P.: High Frequency New Particle Formation in the Himalayas, PNAS, 105, 41, 15666-15671, 2008.
Villani, P., Picard, D., Marchand, N., and Laj, P.: Design and Validation of a 6-Volatility Tandem Differential Mobility Analyzer (VTDMA), Aerosol Sci. Techn., 41(10), 898-906, 2007.

Virkkula, A., Hirsikko, A., Vana, M., Aalto, P. P., Hillamo, R., and Kulmala, M.: Charged particle size distributions and analysis of particle formation events at the Finnish Antarctic research station, Aboa. Boreal Env. Res., 12, 397-408, 2007.

Wehner, B. and Wiedensohler, A.: Long term measurements of submicrometer urban aerosols: statistical analysis for correlations with meteorological conditions and trace gases, Atmos. Chem. Phys., 3, 867-879, doi:10.5194/acp-3-867-2003, 2003.

Wehner, B., Siebert, H., Ansmann, A., Ditas, F., Seifert, P., Stratmann, F., Wiedensohler, A., Apituley, A., Shaw, R. A., Manninen, H. E., and Kulmala, M.: Observations of turbulence-induced new particle formation in the residual layer, Atmos. Chem. Phys., 10, 4319-4330, doi:10.5194/acp-10-4319-2010, 2010.

Yu, F. and Turco, R. P.: Ultrafine aerosol formation via ionmediated nucleation, Geophys. Res. Lett., 27, 883-886, 2000.

Yu, F. and Turco, R.: Case studies of particle formation events observed in boreal forests: implications for nucleation mechanisms, Atmos. Chem. Phys., 8, 6085-6102, doi:10.5194/acp-86085-2008, 2008. 